INTERNATIONAL JOURNAL OF MULTidisciplinARY RESEARCH AND ANALYSis

ISSN(print): 2643-9840, ISSN(online): 2643-9875

Volume 05 Issue 03 March 2022

DOI: 10.47191/ijmra/v5-i3-02, Impact Factor: 6.072

Page No. 591-597

\title{
Integration of Islamic Studies and Sciences: Study of the Implementation and Practice of Scientific Integration at UIN Alauddin Makassar
}

\author{
Penulis Ibrahim ${ }^{1}$, Muhammad Ridha ${ }^{2}$, Yusran $^{3}$, Imamul Hak ${ }^{4}$ \\ 1,2,3,4 Ushuluddin and Philosophy, State Islamic University (UIN) Alauddin Makassar - Indonesia
}

\begin{abstract}
This study examines the implementation and practice of integrating Islamic and general science into the lecture process at the State Islamic University (UIN) Alauddin Makassar. The process and efforts to realize the concept of scientific integration in the realm of policy and the process of its formation will be approached with a historical approach. Meanwhile, the practice of implementing scientific integration guidelines in lectures is approached sociologically, especially the limitations and problems of how this concept is practiced at UIN Alauddin Makassar. The results of this study conclude that at least the last two decades since IAIN changed to UIN ALauddin Makassar, have taken steps, namely: first, the process of seeding the idea of scientific integration, incorporating the idea of scientific integration into the vision and mission and implementing it into university policies that support the integration process. Second, integration efforts at UIN Alauddin are also carried out in the process of teaching courses and writing student scientific papers. Some of the efforts that have been made to realize integrative teaching of courses and scientific works are by attaching verses to courses, teaching integrative courses, implementing team teaching, memorizing chapter 30 for each UIN student and implementing Character Building Training for each student.
\end{abstract}

KEYWORDS: Scientific Integration, Islamic studies, General Science, UIN Alauddin Makassar.

\section{INTRODUCTION}

Leading public universities in Indonesia have struggled with efforts to transform IAIN into UIN for almost two decades. This effort aims to provide a wider space to develop science by creating study programs or faculties with studies of sciences in accordance with Islamic studies. This creation realized in early 2002 when IAIN Syarief Hidayatullah, Jakarta received a Presidential Decree regarding the conversion from IAIN to the State Islamic University, From "Institute " to "University".

This transformation is not merely a term but more than just changing the name of the institution. The authority to open a new faculty aside from Islamic studies is the most prominent and significant change on institution's characteristic which was once known as an institution for Islamic studies to be an institution that provides general subjects such as: medicine, engineering, economics, arts and humanities.

This also happened at UIN Alauddin Makassar. The nuance of science in the last two decades has become different from the previous decade where all lecturers and subjects are based on traditional Islamic scholarship. Many have questioned if IAIN has been able to open a general faculty, then what is its distinction from other higher education institutions that has existed for a long time with general science provided. While this Islamic education institution previously has managed only the faculties of Syari'ah, Tarbiyah, Adab, Da'wah and Ushuluddin, now the general faculty with all general study programs under it also has been opened. If so, what is the distinctive scientific distinction of the lecture process and knowledge development at UIN? This was answered rhetorically by the Chairman of the Committee for the Conversion of IAIN to UIN, the former Chancellor of UIN Alauddin and (currently) the chairman of the Senate of UIN Alauddin, Prof. Dr. H. Qadir Gassing, HT, MS in a speech at the Senate forum that "Scientific integration"i "Other public education institutions only learn general scientific knowledge, then at UIN Alauddin the general faculty will study general sciences along with Islamic studies, while the religious faculties give greater weight to general science than before so that an integration feature between traditional Islamic sciences which mostly comes from the Qur'an and Hadith with general sciences emerges" (minute of senate meeting). 


\section{Integration of Islamic Studies and Sciences: Study of the Implementation and Practice of Scientific Integration at UIN Alauddin Makassar}

However, what is expected, as simply stated as "scientific integration" at the senate meeting mentioned above, is not as simple as mentioning the term. Because in practice, at UIN Alauddin itself, the so-called scientific integration is only represented in the form of grafting verses and hadith into general courses and incorporating general knowledge and science into the Islamic studies faculty. Despite its simplicity, these efforts have been developed in the last few decades and practiced in the learning process to the writing of scientific papers. Therefore, it is important to know further and draw the process of scientific integration at UIN Alauddin Makassar.

\section{METHODOLOGY}

In this study, researchers employ qualitative methods. This research aims to understand the phenomena of what is experienced by research subjects such as behavior, perception, motivation, action, etc., holistically by means of description in the form of words and language, in a certain natural context and by utilizing various scientific methods." In terms of data collection, this research collects archives, deeds of meeting statements, minutes of senate meetings and leadership meetings related to the process of establishing scientific integration regulations at UIN Alauddin Makassar. Informants in this study are lecturers in the sample study programs drawn based on categories representing religious faculties and non-religious faculties. This research was conducted at UIN Alauddin Makassar. The UIN Alauddin Makassar campus changed from IAIN to UIN Alauddin in 2005 under the leadership of the rector Prof. Dr. Azhar Arsyad, MA. The campus is located in Makassar City and in Gowa Regency, South Sulawesi.

\section{RESULTS AND DISCUSSION}

\section{From the 'Cypress Cell' to the Civilized House}

The debate about the paradigm and the form of scientific integration at UIN Alauddin Makassar is actually not something that is 'finished' in the sense of issuing a rector's decision or holding workshops and publishing books related to the theme of scientific integration. Behind it all, there are struggles and competing ideas that have been poured out by at least some of the leading thinkers at UIN to realize or concrete what is meant by scientific integration. In a book entitled Synergy of Religion and Science, Efforts to Build a Center for Islamic Civilization, a number of thinkers, both from within UIN Alauddin and outside UIN Alauddin, contributed ideas about what integration is and how integration is envisioned to be implemented at UIN Alauddin.

One of the quite relevant to provide a conceptual basis for the scientific integration paradigm at UIN Alauddin Makassar is an article written by Prof. Dr. H Azhar Arsyad, MM (2005) entitled Cemara Cell: Integration and Interconnection of Science and Religion. In the article he expresses the need to provide conceptualization as a metaphor for what he called scientific integration. Therefore, he wrote: "It is crucial to formulate a picture of the cypress cell in which integrity and the metaphorical interconnection of roots, grooves, branches and fruits and the transcendental goals of universal science can be realized within a university as we will see later. The image of a fir tree indicates something that is alive, not dead. Cool to look at because it is a tree, it grows and develops and then becomes conical. More and more shady. This tree will bear fruit, and that fruit is the name of a science that will certainly bear fruit again and so on. The parts are integrated and interconnected. The picture of the cell depicts aspects of scientific and technological interconnection, while the fir depicts the ultimate transcendental through Muhammad's apostolate to Allah. iii The argument about the scientific scheme in the IAIN institution needs to be refreshed by changing IAIN to become a UIN in a more universal mission of integrating Islam and science or not dichotomizing Islam and science but putting Islam as an approach to science itself. The aforementioned argument is also supported by an interesting review of the Islamic world and Islamic scholarship in the classical century of Islam as an era in which scientists who were not dichotomous expertise between religion and science.

Another article that also contributes to a discussion of scientific integration at UIN Alauddin belongs to Natsir Mahmud, an academic and professor of Islamic education. He wrote an article entitled The Paradigmatic Foundation of the Islamization of Science. This article describes the importance of the islamisation of sciences in which in European history sciences were secularized and later became the legacy of modern science. One of the important debates that Natsir Mahmud responded to in relation to his idea of Islamizing science was the polemics from scientists regarding, on the one hand, secular sciences and on the other hand Islamized science. As stated in the article: "The problem lies in the will to produce objective science, becoming rigorous science on the one hand, and on the other hand the tendency of Muslim scientists to want science to be born from the heart of Islam, referring to the Qur'an and Sunnah, starting from the process of seeking knowledge, systematizing and analyzing to drawing conclusions. ${ }^{\text {iv }}$

\section{Internalizing Scientific Integration at UIN Alauddin Makassar: Workshop and Training}

This section describes how scientific integration is implemented from its epistemological aspect to its axiological aspect as an illustration of an internalization or transformation. In this case, it will be described how the philosophy of scientific integration 


\section{Integration of Islamic Studies and Sciences: Study of the Implementation and Practice of Scientific Integration at UIN Alauddin Makassar}

that developed at UIN Alauddin as something that seemed to be in the sky then tried to be brought down to earth to become more contextual. In one of Umar Kayam's explanations it is described that the process of application/internalization and transformation is a process of total transfer from an imaginary form to a new, more real figure.

In the implementation of the scientific integration of UIN Alauddin as an internalization and transformation effort, there are three aspects involved. 1) university: physical transformation (physical development), 2) government: political transformation (management), and 3) University: idealistic transformation; academic field. Although this research focuses on the implementation of scientific integration in teaching and scientific work, in its elaboration, these three aspects describe simultaneously or not separately from one another. In general, the implementation of scientific integration at UIN Alauddin is described in the following chart. $^{v}$

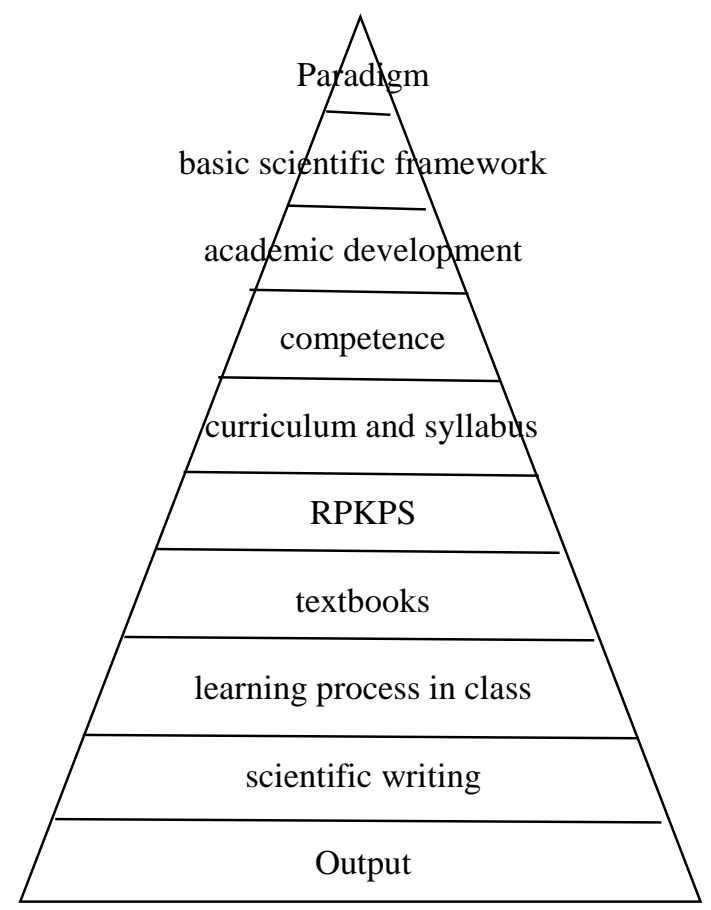

Figure 1. Implementation of Scientific Integration at UIN Alauddin Makassar

\section{Efforts to Apply Scientific Integration: Teaching Practices and Internalization of Values to students}

There are a number of practices that have been carried out in the practice of teaching and writing scientific papers at UIN Alauddin Makassar as a form of implementing the vision of scientific integration. Broadly speaking, the scientific integration found in the field as acknowledged by a number of informants from lecturers, study program managers and students who became informants in this study was an effort to incorporate verses of the Qur'an and Hadith into every general course, attaching verses of the Qur'an and Hadith to every general course. al-Qur'an and Hadith in the process of writing scientific papers, especially for students' final assignments. The lecturers give religious messages at each start of the lecture, memorize 30 juices for each student that must be completed before graduating and provide knowledge such as Arabic for every student in all faculties. The general pattern of scientific integration in a number of fields of science has actually been formulated by the university's academic senate team in 2017 and 2019 which has been published as a scientific integration guidebook. The book provides an overview in a table regarding the general pattern of scientific integration, as shown in the table below ${ }^{\mathrm{vi}}$ : 
Integration of Islamic Studies and Sciences: Study of the Implementation and Practice of Scientific Integration at UIN Alauddin Makassar

Table 1. General Patterns of Integration.

\begin{tabular}{|c|c|c|c|}
\hline & $\begin{array}{ll}\text { NBRANCH } & \text { OF } \\
\text { SCIENCE } & \end{array}$ & CHARACTERISTIC & INTEGRATION \\
\hline \multirow{3}{*}{ I } & Natural Sciences & Studying the natural structure of matter. & \multirow{3}{*}{$\begin{array}{l}\text { There is a creator of nature, namely God, so that } \\
\text { its internal systems and mechanisms run steadily } \\
\text { and can be expressed by humans. } \\
\text { Understanding the nature of matter prevents us } \\
\text { from understanding materialism, because there } \\
\text { is an immaterial force in matter. }\end{array}$} \\
\hline & & $\begin{array}{l}\text { Matter essentially contains something } \\
\text { immaterial, namely energy. Condensed } \\
\text { energy = matter, and sparse matter = } \\
\text { energy } \\
\text { (Albert Einstein) }\end{array}$ & \\
\hline & & $\begin{array}{l}\text { The element of material works } \\
\text { systematically and can be analyzed } \\
\text { mathematically }\end{array}$ & \\
\hline \multirow[t]{2}{*}{ II } & Social Sciences & $\begin{array}{l}\text { Social Sciences include Sociology, } \\
\text { psychology, economics, education, } \\
\text { communication, politics, etc. It examines } \\
\text { the relationship between human beings } \\
\text { who need each other in a community, } \\
\text { governed by an institutionalized order } \\
\text { that develops dynamically following the } \\
\text { changing times. }\end{array}$ & \multirow[t]{2}{*}{$\begin{array}{l}\text { Humans organize their lives by creates the order } \\
\text { produced from their mind. However, humans } \\
\text { still need guidance from the Almighty. Humans } \\
\text { need the absolute from the Most Absolute as a } \\
\text { firm grip beyond what is produced by human } \\
\text { thought. } \\
\text { Spiritual-religious dimension as a therapy to } \\
\text { ward off social shocks, so that humans live on the } \\
\text { earth with peace. Religious spiritual values can } \\
\text { ward off social shocks that hit all aspects of life. }\end{array}$} \\
\hline & & $\begin{array}{l}\text { Social dynamics and changes always } \\
\text { involve social frictions. Humans always } \\
\text { organize their lives to achieve peace. } \\
\text { However, social friction always appears, } \\
\text { destructive actions always get a chance. }\end{array}$ & \\
\hline III & Humanities & $\begin{array}{l}\text { Humanities studies cultural values, } \\
\text { customs, symbolism, language } \\
\text { expressions, etc. The study concerns } \\
\text { value but is described according to } \\
\text { scientific procedures, so that it remains } \\
\text { neutral. }\end{array}$ & $\begin{array}{l}\text { The humanities examine scientific values } \\
\text { objectively, but because the study already } \\
\text { involves values so that it is easy to implement, } \\
\text { especially values that do not conflict with Islamic } \\
\text { thought. }\end{array}$ \\
\hline
\end{tabular}

In an effort to integrate this pattern, the following authors describe the study findings:

\section{A. Attachment of verses of the Qur'an and Hadith in General Lectures}

In our interviews with several major convenors, as we did with Dra. Hj. Andi Nirwana (Head of Study Program of Religion, Faculty of Ushuluddin, Philosophy and Politics) and Sitti Syakira, M.Ag (Secretary of International Relations Program, Faculty of Ushuluddin, Philosophy and Politics at UIN Alauddin Makassar) acknowledge that what has been done so far is related to the practice of integration. Science is to provide the basis for the verses of the Qur'an and hadith for studies or general courses in their respective study programs as well as in the courses they teach respectively. As acknowledged by Mrs. Hj. Nirwana "The integration of knowledge that I understand, which has been practiced for a long time in our study program is to attach verses and hadiths to general courses given to our students. As in the subject of research methods, philosophy of science, and so on." vii

Sitti Syakira, M.Ag admits that "Integration as far as we understand is to provide an overview of the scriptures for each general course that is taught. For me, it is not clear what our integration at UIN will be like. But the practice is like that (attributing verses or hadiths). There are still many shortcomings. But efforts are continuing." 


\section{Integration of Islamic Studies and Sciences: Study of the Implementation and Practice of Scientific Integration at UIN Alauddin Makassar}

The inclusion of the verse is where the verse or hadith is presented in the discussion of the subject or course material (especially in the discussion of general science course material). Yet is still at the surface level of the "meaning" of the verse or hadith that is linked. Of course, it is still generally far from ontological and epistemological discussion, as expected in the concept of scientific integration when opposing the concept of the Islamization of science that developed in the 1980s. Even in some cases of the process of presenting verses (which was later referred to in this study as the inclusion of verses of hadith), the learning process in the classroom seems to return to pattern of the Islamization paradigm, or even more "shallow" because sometimes there are coercions that are not based on systematic argumentation in the teaching process.

As found in this study, the real conditions of teaching religious and general sciences are still in a state of:

- Until now, many course leaders/lecturers have not fully understood the meaning of the intended integration, especially in terms of its application when it will be taught in lecture classes. Except for the understanding that the integration referred to in the learning process at UIN is how in every learning process of any subject that "what is important is the presence of the verses of the Quran and the hadith then that is regarded as integration.

- Both general science and islamic studies lecturers have no specific guidelines regarding the use of verses of the Quran and hadith in the process of integrating the knowledge and subjects..

- General science lecturers who are historically coming from the academic background of general science who were previously unfamiliar with the UIN scientific integration project. On the other hand, religious lecturers are historically coming from religious education pathways that do not recognize well-established scientific integration.

- briefing and training program of Scientific integration that is not run well.

The main obstacle why such application still exists is due to the understanding of the general science lecturers on the meanings of verses and hadiths that are associated with the science being taught. This is due to, among other things:

a. Explanations regarding the meanings of verses or hadiths have their own traditions and scientific methods that require a different and more deeper process.

b. Some lecturers still have a lack experience on using verses and hadiths as a scientific tradition (text civilization) due to their academic background that is not developed in religious educational institutions/institutions, since elementary, junior high, high school, undergraduate to become lecturers.

c. Handbooks and teaching guides in the framework of scientific integration are still underdeveloped, especially for guidance on substantial matters in the process of using verses and hadith in general courses.

d. Incorporating the relevant verse in every scientific paper writing.

The team teaching method has been applied in the teaching process at UIN Alauddin as an effort to integrate science and religion in the subjects. However, this method only worked for about a year and then was discontinued. According to one of our informants, this program was discontinued mainly because islamic studies lecturers were unable to provide detailed references to verses and hadiths for specific scholarships or subjects. Therefore the information is still too general about the importance of seeking knowledge in Islam, high dignity for people seeking knowledge and so on which are still general ethos. ${ }^{\text {vii }}$

\section{B. Integrative Course Teaching Practice}

In general, the process of teaching courses at UIN Alauddin Makassar takes place in three types of course teaching:

\section{General Course Teaching}

The teaching of general courses referred to here is the teaching of subjects that are branching from independent vocational/departmental sciences without unification/integration of ontological aspects. For example teaching general sociology courses, PPKN, Indonesian, Physics, Biology, and English. Of course, the teaching process will take place specifically separately, namely: 1) the teacher according to his capacity as a general course teacher, and 2) the lecture material/syllabus is independent. In the process of teaching this kind of subject, there is a process of applying scientific integration

- the application of morals in accordance with Islamic teachings (verses and hadiths) by creating a lecture contract

- delivery of religious moral messages at the beginning or end of lectures

- prayer readings at the beginning of each lesson

- linking lecture material with several religious arguments, both related to a verse or a hadith of the prophet.

\section{Teaching Religion Courses}

The learning process of Islamic studies subjects also implies the process of teaching courses that are specifically independent ontological and epistemological as a branch of religious science in particular. Of course, the teaching process will take place 


\section{Integration of Islamic Studies and Sciences: Study of the Implementation and Practice of Scientific Integration at UIN Alauddin Makassar}

specifically and separately, namely: 1) the teacher according to his capacity as a lecturer in certain religious subjects, and 2) the lecture material/syllabus is independent from general science. For example, the study of classical texts, tasawwuf, fiqh, kalam, and others. In the process of teaching this kind of subject, there is a process of applying scientific integration:

- the use of religious arguments (verses or hadiths) with evidence from general scientific material.

- the use of technological tools to support the learning process of religious subjects, as a response to the existence of a moral-scientific integrative scientific effort

- presenting contemporary material in the syllabus, especially on material that often clashes between general science and religion

- develop studies of westerners - non-Muslims who happen to also have a concentration on Islamic religious sciences, such as the knowledge of the Koran, hadith or Islamic religious traditions

- the use of contemporary scientific methodologies as enrichment, such as semiotics, hermeneutics.

\section{Integrative Course Teaching}

The teaching of integrative courses is teaching that teaches courses that are the result of scientific integration at the most basic level in each type of science developed by the study programs at UIN alauddin. That each study program, due to the demands of scientific integration at UIN Alauddin, must present one or two types of courses in the learning curriculum which ontologically undergo a process of scientific integration as in the general study program which in addition to presenting general religious subjects, must also specifically present integrative (religious-general) courses such as interpretation of verses or hadiths on politics, social, law, education, science, technology, agriculture, animal husbandry, business, economics and others. On the other hand, in the religious studies program, the religious sciences present integrative courses such as hadith, law and government, quranic psychology, scientific interpretation, and others.

In the context of teaching this integrative course, there is a cross-section of teachers, namely; Religious lecturers teach in general study programs, and vice versa. However, based on the data that has been collected, this teacher exchange is still dominated by the use of religious lecturers in general studies programs to teach integrative sciences, while the use of general lecturers in religious studies programs is still very minimal. This is because "that the scientific integration project of UIN is still in the understanding that the most important of the sciences on campus are religious studies, and general sciences that must welcome this scientific integration project more. In one of the integration FGDs, several participants described that religious knowledge at UIN was the earlier one, the host, knowledge that has survived and will save, science that contains absolute truth, therefore general science that is present at UIN must ask for guidance from scientists. religious knowledge in order to be safe". Here we present a table of scientific integration guidelines published by the university's academic senate:

\section{Table 2. Pattern of Integration Applications in Lectures}

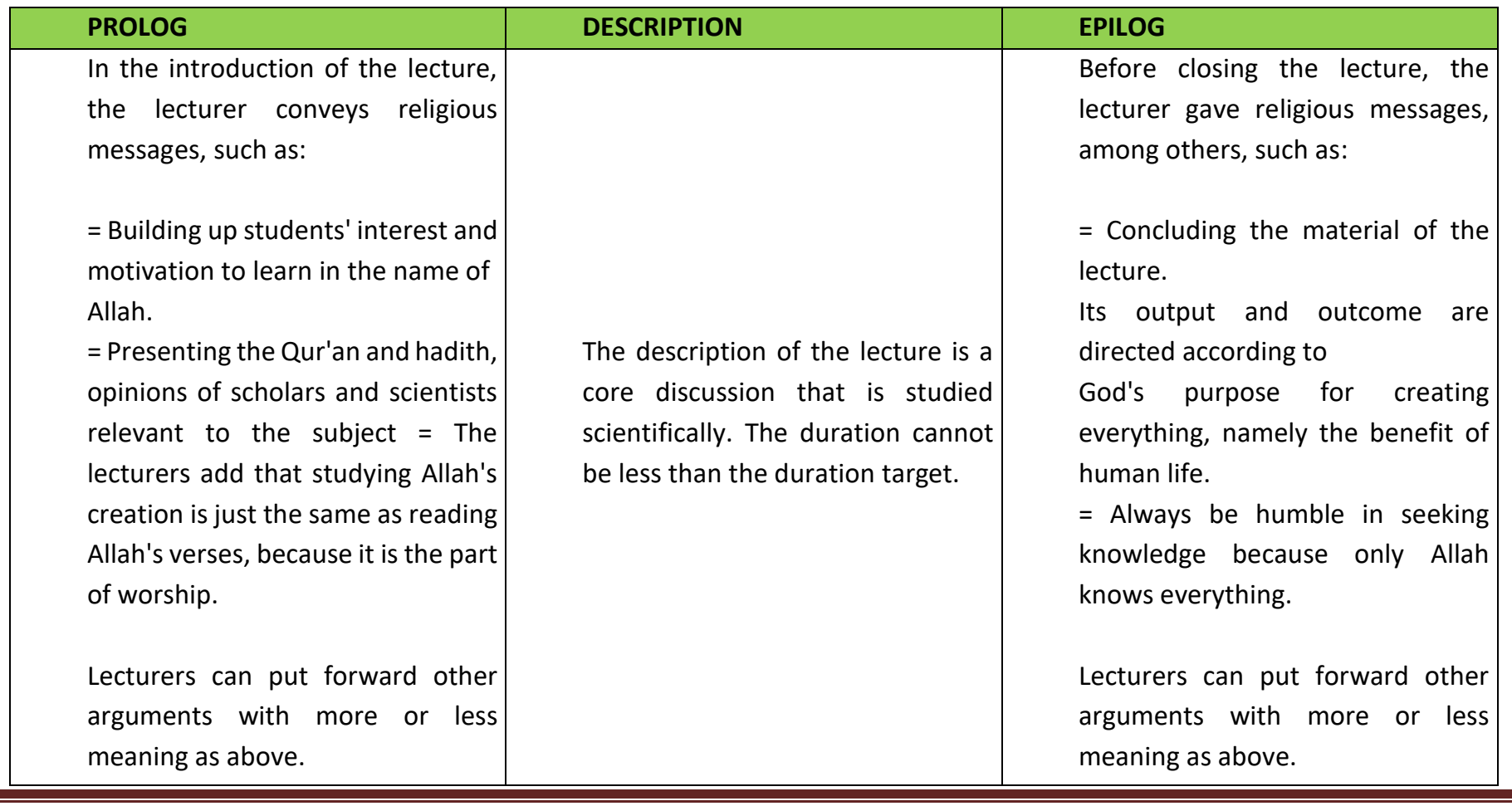




\section{Integration of Islamic Studies and Sciences: Study of the Implementation and Practice of Scientific Integration at UIN Alauddin Makassar}

\section{Religious Messages in the Practice of Lectures and Memorizing Short Surahs (Al-Qur'an juz 30)}

In instilling religious knowledge, especially etiquette for students, each course always begins by providing motivation and universal messages of religion to students. As in the ushuluddin faculty, it is proposed in several discussions at educational meetings every semester to implement this. "It is hoped that every lecturer will give some kind of tausiah before entering the core discussion of the subjects being taught".ix

Until now, all faculties at UIN Alauddin require students to memorize short surahs of juz 30 in the Qur'an. This memorization is delivered directly in front of the academic advisor. If students pass the memorization of juz 30, then students can take the thesis result exam and advance to the next stage. This is based on the rector's policy in the era of prof. Dr. H. Qadir Gassing, HT MS, namely the Decree of the Chancellor of UIN Alauddin Makassar number 129 D of 2013 concerning the Implementation of Scientific Integration for students of UIN Alauddin Makassar. This decree requires students to understand basic religious messages and at least memorize al-Qur'an juz 30. This regulation also encourages the function of CBT to encourage students' personalities with integrative character and ethos.

\section{CONCLUSION}

Based on the description and discussion of the research results, this study concludes that the scientific integration promoted at UIN Alauddin Makassar has been going on for at least the last two decades since IAIN changed to UIN Alauddin Makassar. The steps taken start from, first, the process of seeding the idea of scientific integration, incorporating the idea of scientific integration into the vision and mission and implementing it into university policies that support the integration process. Second, science integration at UIN Alauddin is also carried out in the learning process and student scientific papers. Several efforts have been made to apply integrative teaching of courses and scientific works, including incorporating verses to courses, teaching integrative courses, implementing team teaching, memorizing chapter 30 for each UIN student and implementing character building training for each student.

\section{RECOMMENDATION}

From the results of the search and data collection to the discussion of the findings, this study recommends two things. First, carry out a movement to re-implement scientific integration as a whole for all lecturers and study program managers so that the forms of integration that have been formulated in the scientific integration guidelines that have been published by the university's academic Senate can be conveyed. Second, there is a mass production of scientific integration books that have been compiled so that there are standard guidelines for lecturers, students and study program managers to implement scientific integration according to the procedures set by the institution.

\section{Acknowledgments}

The Author would like to thank UIN Alauddin Makassar for funding support through the 2019 Litapdimas program.

\section{REFERENCES}

1) Minutes of senate meeting.

2) Lexi. J Moleong, Qualitative Research Methodology, (33th Cet: Bandung: Rosdakarya: 2014) p. 6

3) Azhar Arsyad. Cemara Cell Integration and Interconnection of Science and Religion in Nurman Said, Wahyuddin Halim, Muhammad Sabri (Editor) Synergy of Religion and Science (Makassar: ALauddin press, 2005) p. 93

4) Natsir Mahmud The paradigmatic foundation of the Islamization of Science in Nurman Said, Wahyuddin Halim, Muhammad Sabri (Editor) Synergy of Religion and Science (Makassar: Alauddin press, 2005) p.128

5) The pyramid of Knowledge science (-Ashlah al-Manifest Sadra). See Mohsen Gharawiyan, Introduction to understanding Islamic philosophy textbooks: explanations for approaching analysis of Islamic philosophical theory, trans. Muhammad Nur Djabir (Jakarta: Sadra Press, 2012), p. 102.

6) Guidelines for scientific integration in UIN Alauddin Makassar 2019 vii Siti Syakira and Dra. Hj. Andi Nirwana, M.Ag, interview (8 October 2019) viii Wahyuddin Halim, P.hD, interview (7 October 2019) ix Dr. Indo Santalia, M.Ag, interview (5 October 2019)

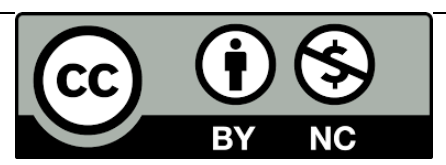

There is an Open Access article, distributed under the term of the Creative Commons Attribution - Non Commercial 4.0 International (CC BY-NC 4.0) (https://creativecommons.org/licenses/by-nc/4.0/), which permits remixing, adapting and building upon the work for non-commercial use, provided the original work is properly cited. 